\title{
Development of In-Can Melting Process and Equipment, 1979 and 1980
}

\author{
L. L. Petkus \\ D. E. Larson \\ W. J. Bjorklund \\ L. K. Holton
}

September 1981

Prepared for the U.S. Department of Energy under Contract DE-AC06-76RLO 1830

Pacific Northwest Laboratory

Operated for the U.S. Department of Energy by Battelle Memorial Institute 
This report was prepared as an account of work sponsored by the United States Government. Neither the United States nor the Department of Energy, nor any of their employees, nor any of their contractors, subcontractors, or their employees, makes any warranty, express or implied, or assumes any legal liability or responsibility for the accuracy. completeness or usefulness of any information, apparatus, product or process disclosed, or represents that its use would not infringe privately owned rights.

The views. opinions and conclusions contained in this report are those of the contractor and do not necessarily represent those of the United States Government or the United States Department of Energy.

\author{
PACIFIC NORTHWEST LABORATORY \\ operated by \\ BATTELLE \\ for the \\ UNITED STATES DEPARTMENT OF ENERGY \\ Under Contract DE-AC06-76RLOO 1830
}

\author{
Printed in the United States of America \\ Available from \\ National Technical Information Service \\ United States Department of Commerce \\ 5285 Port Royal Road \\ Springfield, Virginia 22151
}

Price: Printed Copy $\$$ $\because$ Microfiche $\$ 3.00$

$\begin{array}{cc}\text { •Pages } & \begin{array}{c}\text { NTIS } \\ \text { Selling Pric }\end{array} \\ & \\ 001-025 & \$ 4.00 \\ 026-050 & \$ 4.50 \\ 051-075 & \$ 5.25 \\ 076-100 & \$ 6.00 \\ 101-125 & \$ 6.50 \\ 126-150 & \$ 7.25 \\ 151-175 & \$ 8.00 \\ 176-200 & \$ 9.00 \\ 201-225 & \$ 9.25 \\ 226-250 & \$ 9.50 \\ 251-275 & \$ 10.75 \\ 276-300 & \$ 11.00 \\ & \end{array}$


OEVELOPMENT OF IN-CAN MELTING PROCESS

AND EQUIPMENT, 1979 AND 1980

L. L. Petkus

D. E. Larson

W. J. Bjork lund

L. K. Holton

September 1981

Prepared for

the U.S. Department of Energy

under Contract DE-ACO6-76RLO 1830

Pacific Northwest Laboratory

Richland, Washington 99352 
In 1979 and 1980 nonradioactive process testing continued at Pacific Northwest Laboratory (PNL) with the in-can melter. The testing is part of an investigation into the applicability of this vitrification process to various calcined high-level and incinerator ash radioactive wastes. The investigation discussed in this report concentrated on how waste composition and canister fins affect in-can melter capacity and how waste composition affects glass quality. Process performance proved to be generally satisfactory.

Pilot-scale in-can melter runs were performed between July 1979 and June 1980 with synthetic, nonradioactive, high-level wastes to produce eight canisters of glass. The synthetic wastes processed included high-level wastes from Savannah River, West Valley, and Idaho chemical processing plants, as well as transuranic ash waste.

Full-scale in-can melter runs using nonradioactive materials were conducted between March 1979 and August 1980, producing ten canisters of glass. of the ten canisters, nine contained Savannah River Plant glass and one canister contained glass from synthetic zirconia calcine waste from the Idaho Chemical Processing Plant. In a1l, about 11.4 tonnes of glass was produced in test runs.

During this test period, equipment development was minimal. In the fullscale in-can melter furnace, the baffles separating the six heating zones were removed because problems were encountered with baffle warping. Removing the baffles did not produce much difference on the power distribution of the heating zones. A remotely operated section, which connects the spray calciner to the canister while the canister is being filled, was also tested for its functional operating ability. This connecting section enables remote placement and removal of a canister in a stationary in-can melter. The basic concept of the connecting section was demonstrated, although some problems were encountered with calcine plugging. Additional refinement of the connecting section design is needed. 


\section{SUMMARY}

ABBREV IATIONS

INTRODUCTION

CONCLUSIONS AND RECOMMENDATIONS

DESCRIPTION OF IN-CAN MELTER

CONCEPT

EQUIPMENT DESCRIPTION

WASTE COMPOSITIONS $\cdot$ •

IN-CAN MELTER PROCESS TESTING .

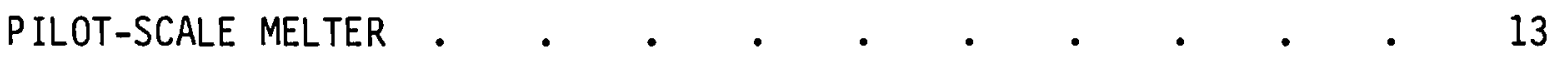

ICM-29 $\quad \cdot \quad \cdot \quad \cdot \quad \cdot \quad \cdot \quad \cdot \quad \cdot \quad \cdot \quad \cdot \quad \cdot \quad \cdot 13$

ICM-30, 31, 34 and 35 . $. \quad . \quad . \quad . \quad . \quad . \quad . \quad 16$

$\mathrm{ICM}-32$. $\quad . \quad \cdot \quad \cdot \quad \cdot \quad \cdot \quad \cdot \quad \cdot \quad \cdot 22$

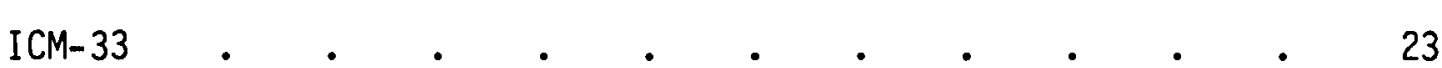

ICM-36 • • . . . . . . . . . 24

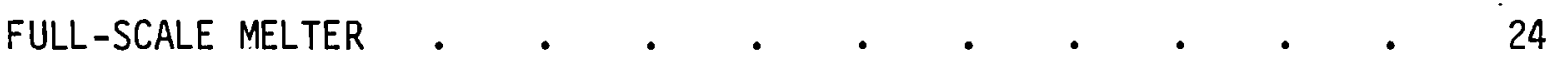

FS-ICM-20 to 23 .

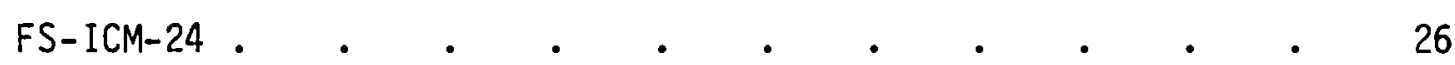

FS-ICM-25 • • .

FS-ICM-26 and 27 . $\quad . \quad$. . . . . . . 27

FS-ICM-28 and 29 . 


\section{FIGURES}

1 Spray Calciner/In-Can Melter Process . . . . . 6

2 Pilot-Scale In-Can Melter . . . . . . . . 8

3 Full-Scale Spray Calciner/In-Can Melter . . . . . 10

4 Remote Connecting Section . . . . . . . . 12

5 Time Surmary FS-ICM-26 . . . . . . . . . . . . 29

6 Time Summary FS-ICM-27 . . . . . . . . . . . 30

\section{TABLES}

1 Summary of Pilot-Scale In-Can Melter Runs . . . . . 14

2 Summary of Full-Scale In-Can Melter Runs . . . . . 15

3 Mean Off-Gas Concentrations and Standard Deviations for the TRU Run . . . . . . . . . . 17

4 Mean Volume Percents for Each Component of the Off-Gas

From the TRU Run . . . . . . . . . . 18

5 Chemical Composition of Neutralized High-Level Waste Stored in Tank 802 and Acidic Waste Stored in Tark 804, mole/liter . 19

6 Physical Characteristics of Laboratory and Pilot-Plant Glasses • • • • • • • • • • 21

7 Physical Characteristics of Laboratory and Pilot-Plant Glasses • • • • • • • • • • • • 22

8 Leach Test Comparison--Tank 802 Neutral Sludge and Recovered Fission Products with Borosilicate Glass 76-68 . . . 
$\begin{array}{ll}\text { OWPF } & \text { defense waste processing facility } \\ \text { FS } & \text { full scale } \\ \text { HLLW } & \text { high-level liquid waste } \\ \text { ICM } & \text { in-can melter } \\ \text { NA } & \text { not applicable } \\ \text { NFS } & \text { Nuclear Fuel Services } \\ \text { ORNL } & \text { Oak Ridge National Laboratory } \\ \text { PNL } & \text { Pacific Northwest Laboratory } \\ \text { PS } & \text { pilot scale } \\ \text { SC } & \text { spray calciner } \\ \text { SCR } & \text { silicon controlled rectifier } \\ \text { SRL } & \text { Savannah River Laboratory } \\ \text { SST } & \text { stainless steel } \\ \text { TOS } & \text { technical data summary } \\ \text { TRU } & \text { transuranic } \\ \text { WSEP } & \text { waste solidification engineering prototypes }\end{array}$ 


\section{INTRODUCTION}

The in-can melting (ICM) process which is used to vitrify high-level radioactive waste has been under development for over ten years at Pacific Northwest Laboratory under the sponsorship of the Department of Energy and its predecessors. In the ICM process the calcined high-level waste and glassforming chemicals are fed into a canister in a furnace. The waste is heated and vitrified within the canister, which serves as the container for the final waste product. Development of the in-can melting process can be traced to the FINGAL process developed in England (E11iot et al. 1960; Grover et al. 1966); the process feeds a slurry of high-level liquid waste (HLLW) and glass-forming chemicals into a heated canister. Several variations of pot calcination or pot melting were developed at Oak Ridge National Laboratory (ORNL) around the time the FINGAL process was introduced.

Between 1966 and 1970, several waste solidification processes were demonstrated on an engineering scale with radioactive materials in the Waste Solidification Engineering Prototypes (WSEP) program at PNL (MCElroy et al. 1972) to produce 33 canisters of solidified radioactive product. The heated-wall spray calciner was used to convert the high-level waste to a calcine (Bonner et al. 1976). The calcine flowed directly from the calciner into a heated steel canister. Borosilicate glass formers that had been premelted and cooled to form a frit were added to the pot as it filled to produce a glass melt. This innovation in the rising-level glass process significantly improved the glass production rate. After the canister was filled with melt, it was cooled to produce a vitrified waste form. Two canisters of vitrified HLLW were produced by this in-pot melting process in the WSEP program (MCElroy et a1. 1972).

In 1974, additional development of the in-can melting process using nonradioactive feeds was undertaken. Pilot-scale equipment was used to demonstrate that the glass compositions developed so far were compatible with canisters fabricated of 304L stainless steel. After various process and equipment developments were made, a full-scale nonradioactive unit was constructed for demonstration. This furnace was used to investigate the operation of the process equipment at plant design rates. An earlier report (Blair 1979) described 
the development and demonstration of the in-can melter from 1974 to 1978. The report closely followed the progress of each phase of the in-can melter equipment through the initial demonstration runs of commercial and defense wastes.

The Nuclear Waste Vitrification Program was set up by PNL for the Department Energy to demonstrate the SCI/ICM process and produce borosilicate glass from high-level waste generated from spent nuclear-power-reactor fuels. In 1979 two canisters, 20 centimeters (cm) in diameter by $244 \mathrm{~cm}$ long, were produced with both vessels containing $94 \mathrm{~L}$ of glass bearing 370 kilocuries (kCi) of radioactivity.

This document describes the development of the in-can melting process using nonradioactive feeds and equipment that has taken place from 1979 through 1980. Most of the work performed in this period was directed toward the immobilization of defense wastes. The process chemistry and product quality are only discussed as they pertain to the equipment development. Individual topics are covered through the range of experiments, followed by a summary of each run in chronological order. 


\section{CONCLUSIONS AND RECOMMENDATIONS}

The following conclusions and recommendations were developed from the in-can melter waste vitrification studies of 1979 and 1980:

- The maximum demonstrated processing rate of the full-scale in-can melter with a 7-ft-high by 24-in.-diameter canister containing 16 metal, internal heat-transfer fins was about $85 \mathrm{~kg}$ of glass per hour for a defense waste feed not containing combustibles. The furnace power consumption was $61 \mathrm{~kW}$ at this capacity.

- The maximum demonstrated processing rate of the full-scale in-can melter with a 7-ft-high by 24-in.-diameter canister containing no internal heat transfer fins was about $81 \mathrm{~kg}$ of glass per hour with a feed that provided an exothermic reaction. The reaction involved the burning of coal and organic chemicals during solidification of the feed. The power supplied by the furnace was $90 \mathrm{~kW}$ at this rate.

- The baffles installed in the full-scale melter furnace to separate each heating section warped significantly when both Incone $1-601{ }^{\circledR}$ and ceramic-board split dividers were used. The removal of these separators from the furnace has no significant effect on the power use and distribution in each zone of the melter.

- A remotely operated connecting section was tested and shown to be feasible. Operations difficulties due to calcine plugging indicate that the design must be refined.

- Process testing with Savannah River, Idaho, and West Valley Processing Plant synthetic, high-level wastes and transuranic ash waste further demonstrated that the performance of the ICM process depends on the composition of the wastes. Before equipment is designed, the ICM process technology should be tested on new waste compositions.

(ब) Trademark of Huntington Alloys Division of the International Nickel Company, Inc., Huntington, West Virginia. 
- Some defense wastes have a tendency to foam, which limits the capacity of the system.

- The transuranic ash was slow to dissolve into the glass during the processing.

- The presence of reducing agents in the feed to the ICM must be controlled to prevent metal precipitation from the glass. 


\section{DESCRIPTION OF IN-CAN MELTER}

The in-can-melter process equipment and waste compositions are briefly described in this section. In-depth discussions of these topics have been provided in other documents (Blair 1979; Larson 1980; Petkus, Gorton and Blair 1981).

\section{CONCEPT}

High-level waste calcine and glass-forming chemicals are fed into a canister contained in a furnace. The furnace heats and melts the chemicals as they are fed to the canisters. Metal fins may be placed in the canister to promote heat transfer within the canister and increase the melting rate. A glassy product is produced on cooling. When melting takes place, the calcine and glass formers are greatly reduced in volume. To fill a canister, batch materials (feed chemicals) are continuously added and allowed to melt. By minimizing the inventory of unmelted batch in the canister, the highest melting rates can be achieved. When the canister is full, it becomes the storage container for the glass.

The spray calciner/in-can melter process (Figure 1 ) is the outgrowth of this concept for nuclear waste solidification. A heated-wall spray calciner is used to convert HLLW to a dry powder. The powder falls down through a transition piece simultaneously with the rest of the glass formers, usually in the form of a glass frit. The frit and calcine addition rates are adjusted to match the melting rate. When one canister is full, the flow of glass formers is diverted to another furnace and hot canister. Meanwhile, the full canister is kept at temperature to allow the remaining batch to melt. Once all of the glass has melted, the canister is cooled, removed from the furnace, and a new canister is put in its place.

The simplicity of the ICM process is advantageous, because the processing of HLLW is necessarily remote. Everything that is put into the melter, except a small fraction of volatile species, is contained in the disposal canister. The permanent ICM equipment is not degraded by the corrosiveness of the melt, 


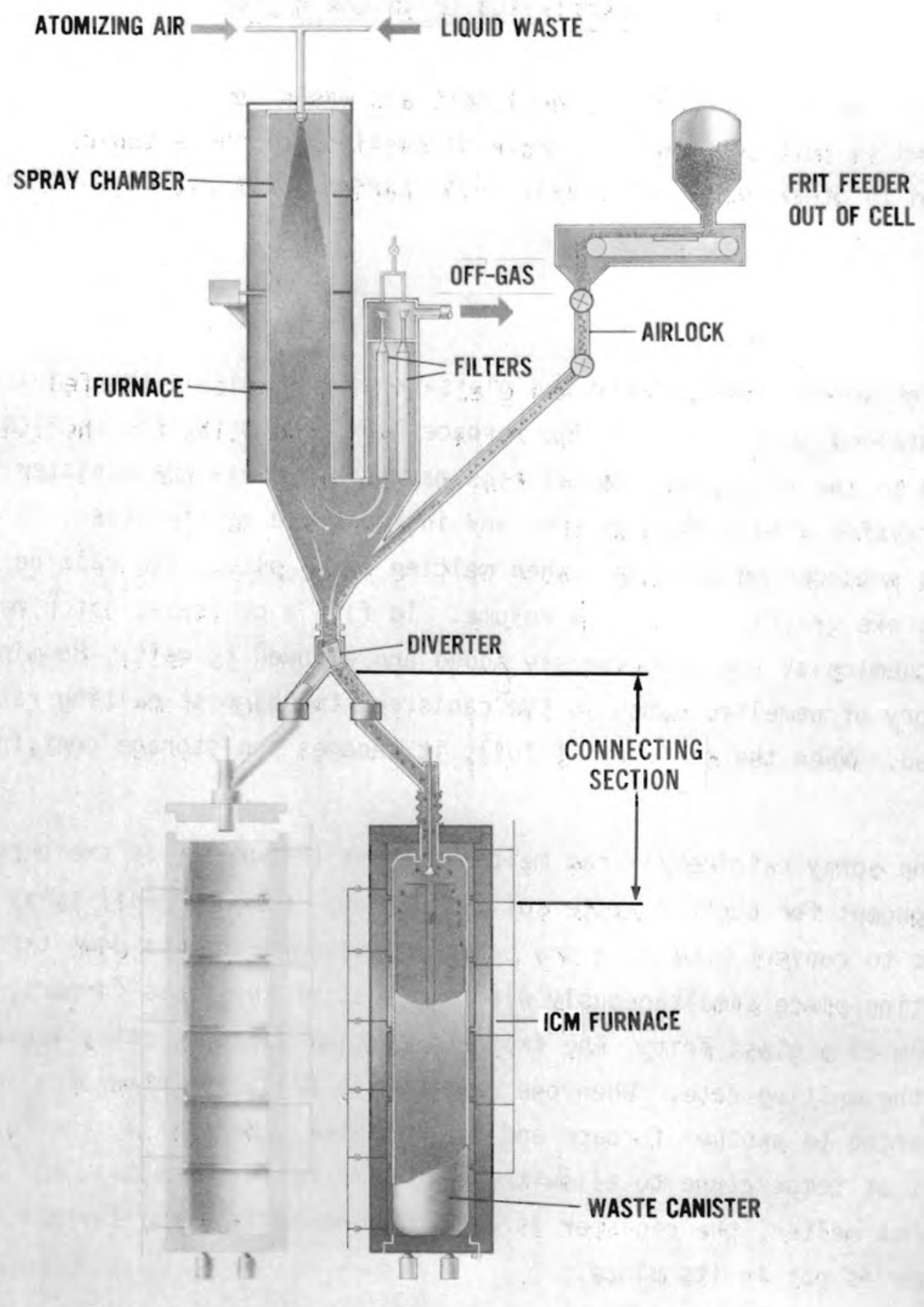

FIGURE 1. Spray Calciner/In-Can Melter Process 
nor is the furnace directly contaminated by the waste. The process does not restrict glass formulation other than that the canister must be able to withstand processing temperatures and corrosion. Reducing agents can be used to eliminate sulfate (which is not very soluble in glass) or other chemical additives from the glass.

Processing the waste in the canister does have some disadvantages, however. Because the canister is subjected to severe thermal and tensile stresses, it must be appropriately designed and constructed of suitable materials. Moreover, batching errors (incorrect frit-to-calcine ratio) are very difficult to correct, and it is difficult to nondestructively verify the quality of the vitrified product.

\section{EQUIPMENT DESCRIPTION}

Of the five ICM furnaces at PNL, two in-can melter furnaces have principally been used in the nonradioactive development program. A pilot-scale unit, in service since 1974, has been used to demonstrate glass formulations and equipment interaction for several types of waste dryers and flowsheets. The full-scale furnace was designed with a capacity high enough to process, in conjunction with a second furnace, the HLLW from 1500 tonnes of uranium fuel per year. The full-scale furnace was put into operation in 1977.

\section{Pilot-Scale Furnace}

The pilot-scale furnace is a single-zone, resistance-heated furnace (Figure 2). The cavity of the furnace is $49.5 \mathrm{~cm}$ (19.5 in.) in diameter by $139.7 \mathrm{~cm}$ (55 in.) ta11. A canister is supended in the furnace on a load ce 11 that monitors weight gain. The canister extends out of the furnace and connects to its feeder/off-gas connection with a bellows assembly. A split insulating lid fits in the top of the furnace around the canister to minimize convective heat loss. The furnace has a power rating of $70 \mathrm{~kW}$ and a maximum temperature of $1300^{\circ} \mathrm{C}$. Temperature is controlled by a 3-mode controller through a silicon controlled rectifier. Melting capacities as high as 35 kilograms per hour $(\mathrm{kg} / \mathrm{h})$ of glass have been demonstrated for a $21-\mathrm{cm}$ ( 8 in.) canister. 


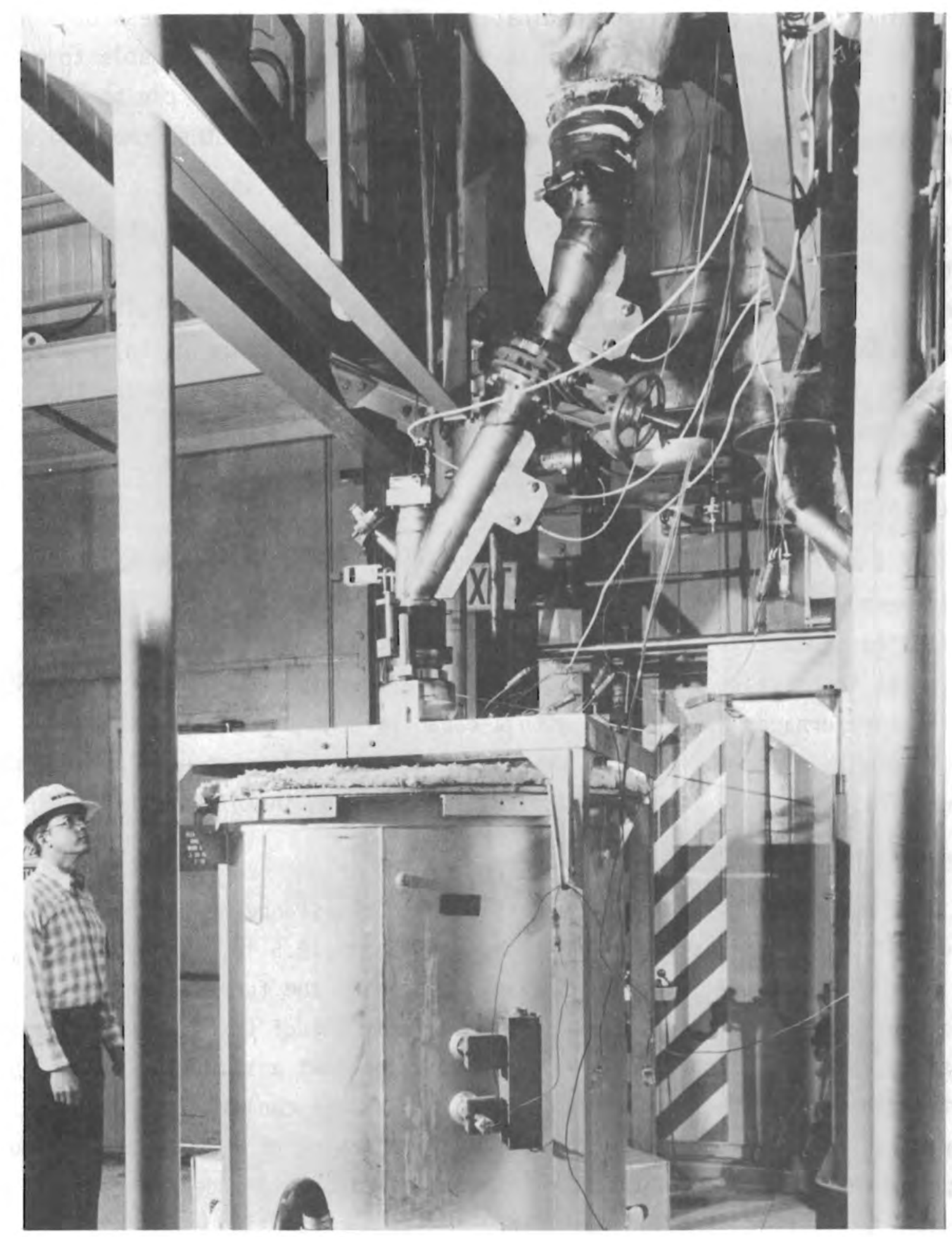

FIGURE 2. Pilot-Scale In-Can Melter 
The pilot-scale furnace effectively simulates the full-scale equipment. Although it does not have all of the same features, many process problem areas can be identified during pilot-scale runs. Materials handling and melter behavior are both conveniently characterized with this equipment.

\section{Full-Scale Furnace}

The full-scale furnace (Figure 3 ) was designed to demonstrate full-scale melting rates, but due to the physical limitations of the available space, the furnace will only accommodate a 2.13-m (7-ft) tall canister. [A 3.05-m $(10-\mathrm{ft})$ canister is being considered for plant applications.] This modification reduces the overall melting rate for the unit and is thus a conservative factor in the demonstration. The furnace has six independently controlled heating zones and 48 silicon carbide heating elements with a total power rating of 210 kilovolt amperes (KVA), and a maximum temperature of $1200^{\circ} \mathrm{C}$. The operating cavity is $71.1-\mathrm{cm}\left(28-\mathrm{in}_{0}\right)$ in diameter by $213.4-\mathrm{cm}\left(84-\mathrm{in}_{.}\right)$tall. The canister is totally immersed in the heated furnace, which is designed for bottom canister support and is insulated with 6 in. of low-density ceramic fiber blanket, which has a low heat capacity for faster heat-up and cool-down rates. Rates have been demonstrated as high as $100 \mathrm{~kg} / \mathrm{h}$ in a $61-\mathrm{cm}(24-\mathrm{in.})$ -

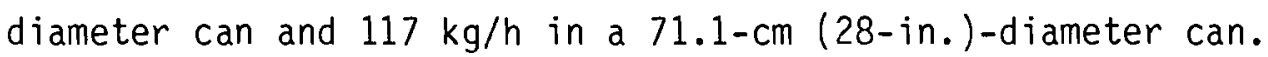

The furnace was originally fitted with zone divider plates to better separate each zone for process control. The dividers were ceramic filled, 16-gauge Incone $1^{\circledR}$ sheet. These dividers were constrained in the furnace and, when distorted by thermal expansion, seized on the canister. All of the plates were removed with the canister and were replaced by $2.54-\mathrm{cm}(1-$ in.)-thick ceramic board. The board was smaller and was split to accommodate thermal expansion. When the furnace was brought to temperature, the ceramic board collapsed and fell from the internal furnace supports. It became apparent from the runs that the entire canister had to be kept hot to maximize available heat transfer area. Keeping the entire canister hot lessened the need for good zone definition and enabled us to leave the divider plates out.

Improvements in the power monitoring system renewed interest in zone definition. To divide the zones, heavier 10 -guage Incone ${ }^{\circledR}$ sheet was used. The sheet was sized and split to allow for thermal expansion. During two 


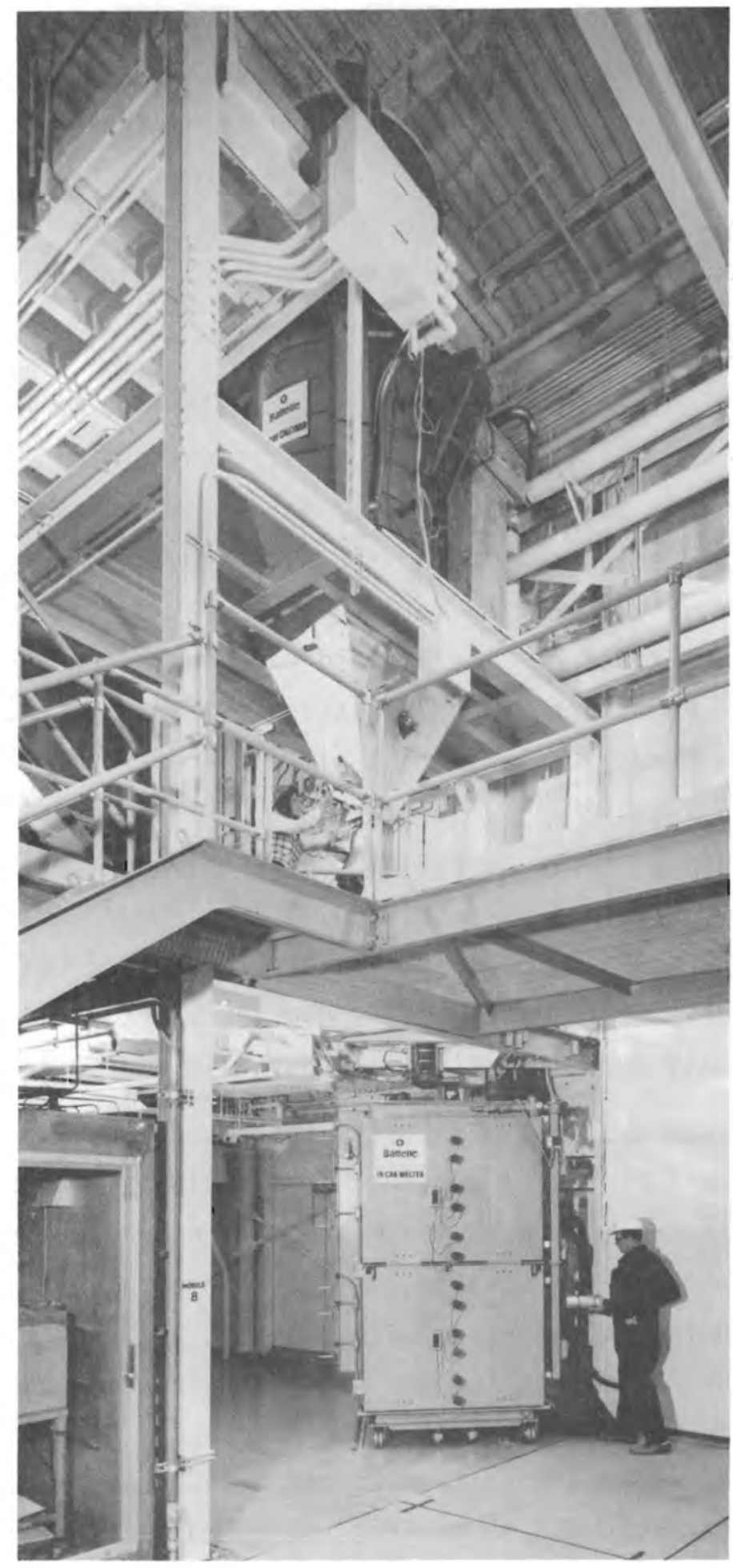

FIGURE 3. Full-Scale Spray Calciner/In-Can Melter 
thermal cycles of these dividers, the Incone ${ }^{\circledR}$ plate had warped enough to cause damage to the heating element. The plates were then removed. Much of the cooling duct work was also removed at this time because of severe warping.

Power monitoring during the runs did not show much difference between having and not having the dividers. Because of the questionable value of having zone dividers and because of the difficulty of getting equipment that will stand up to the temperature cycles in the furnace, no effort was made to replace the zone dividers.

We designed a remotely-operated device to connect the ICM canisters to the spray calciner (Figure 4). Two arms are necessary to divert calcine flow to the spray calciner, but to demonstrate this concept, a single arm was designed and built (Petkus, Gorton, and Blair 1981). The arm swings radialiy from the spray calciner cone, allowing the canister to be removed from the furnace by overhead crane. When the arm is over a canister, a cone valve is lowered on a screw, which in turn lowers a gimbled, free swinging spout that seals to the can through the use of a weight on the spout pressing on a flexible metal seal. Bellows and telescoping tubes are used to provide the necessary flexibility. Experience with this connecting device is reported elsewhere (Petkus, Gorton, and Blair 1981) and is summarized in the experience section of this paper.

\section{WASTE COMPOSITIONS}

During the initial development stage of the ICM process, 14 different simulated waste compositions and 12 different frit compositions were tested in various combinations (Blair 1979). During the last two years of development, several variations of the Savannah River defense waste processing facility (DWPF) have been tested along with TRU ash (Mellinger et al. 1980), Idaho Chemical Processing Plant waste (Bjorklund et a1. 1980), and Nuclear Fuel Services vitrification flowsheets (Holton et al. 1981). The above references should be consulted for processing composition and chemistry details. 


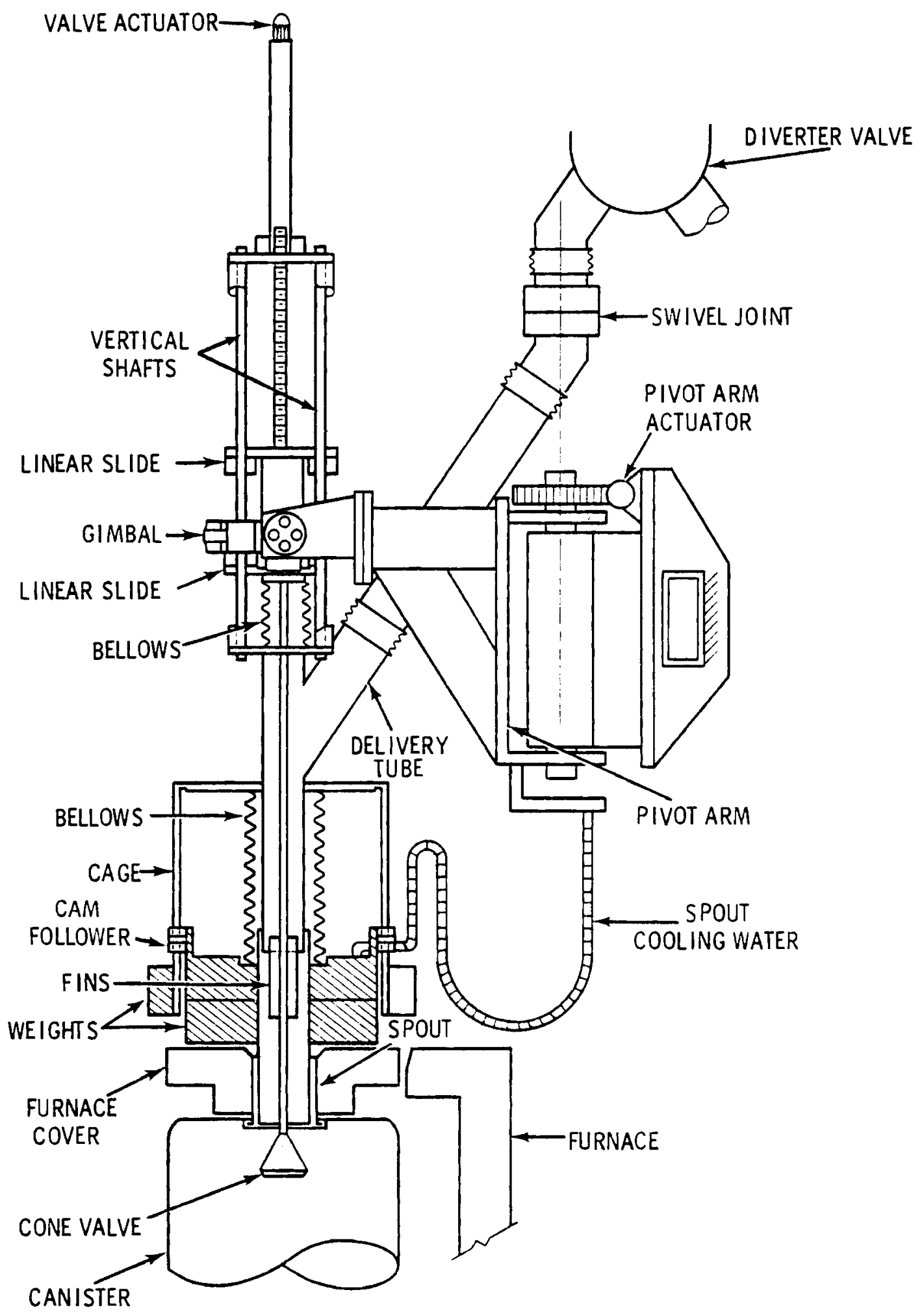

FIGURE 4. Remote Connecting Section 


\section{IN-CAN MELTER PROCESS TESTING}

Since 1974 over $24,750 \mathrm{~kg}$ of vitrified, simulated high-level nuclear waste has been processed in the ICM at PNL. This weight represents 72 canisters processed and over 900 hours $(h)$ of operating experience. During the development period between 1974 and 1978, 54 canisters were produced; process runs for these canisters are individually summarized in the first development report (Blair 1979). This section contains a brief description of process

runs for the 17 canisters produced over the past two years. Tables 1 and 2 contain run summaries that indicate operating parameters and feed, product, and canister characteristics. Different nomenclature is used to identify different simulated wastes, frit compositions, and mixing ratios (SRP Waste--Blair 1979; ICPP Waste--Bjorklund et al. 1980; NFS Waste--Holton et al. 1981; TRU Waste--Mellinger et al. 1980).

The products of most of the ICM runs were sampled by removing a section of the side of the canister, photographing the exposed product, then mining or core-drilling samples from the glass for microscopic examination, density determination, and leach resistance testing. More detailed characterizations of some samples were made with x-ray diffraction and the scanning electron microscope (Ross et al. and Lucas et al. 1981).

The process off-gas from the ICM runs was treated by passing it through the system built for the spray calciner (Bonner et al. 1976). This system included a venturi scrubber, a condenser, and a packed column scrubber. When the melter was operated directly coupled to a calciner, the exhaust initially passed through sintered-metal filters.

\section{PILOT-SCALE MELTER}

The ICM process runs ICM-29 through 36 were performed using the pilotscale in-can melter.

$\underline{\text { ICM-29 }}$

Ash from incinerated, simulated transuranic (TRU) waste was vitrified to demonstrate the feasibility of immobilizing such a waste. The ash was mixed with powdered glass-forming chemicals (Mellinger et al. 1979) and hand dumped 


\section{TABLE 1. Summary of Pilot-Scale In-Can Melter Runs}

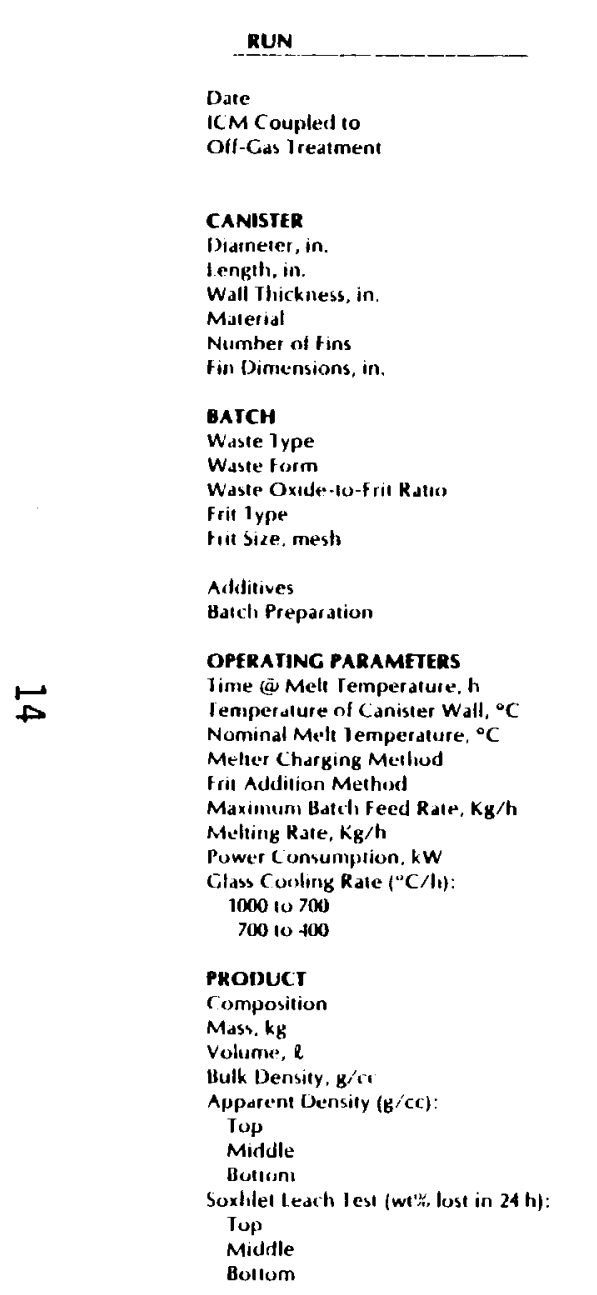

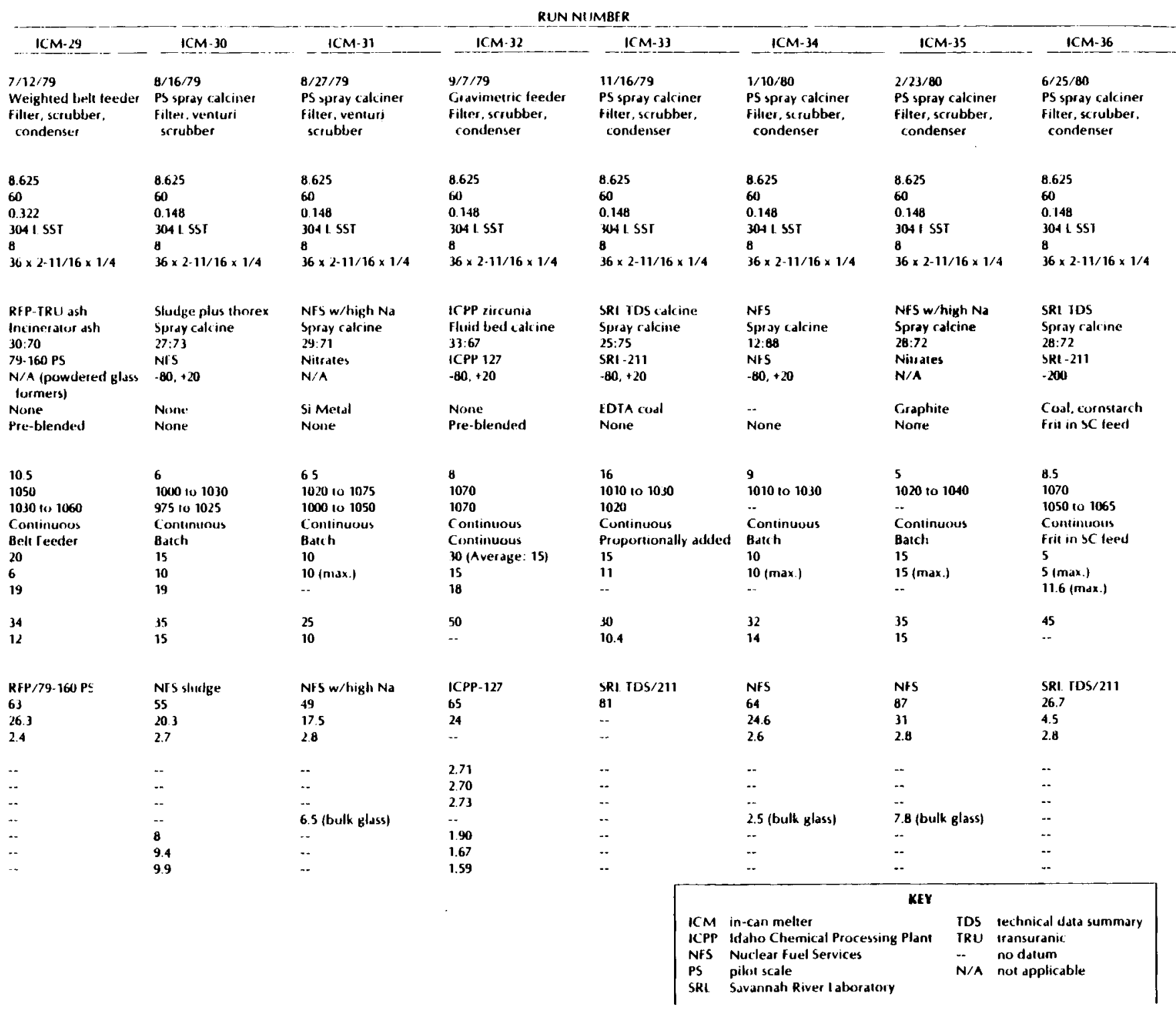




\section{TABLE 2. Summary of Full-Scale In-Can Melter Runs}

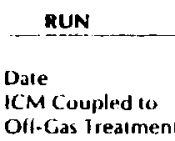

\section{CANISTER}

Diameter, in

Wall Thickness, in

Material

Number of Fins

Batch

Waste 1 ype

Waste Oxide-to-trit Ratio

Frit Type

Frit Size, mesh

Additives

Hutch Preparation

OPERATING PARAMFTERS

Nemperature. 11 .

Nentinal Mell Temperature, ${ }^{\circ} \mathrm{C}$

Melter Charging Method

Maximumb Batch Feed Rate, $\mathrm{Kg} / \mathrm{h}$

Maximumn Batch Fed
Melting Rate, $\mathrm{Kg} / \mathrm{h}$

Power Consumption, $\mathrm{kW}$

Glass Cooling Rate $\left({ }^{\circ} \mathrm{C} / \mathrm{h}\right)$ :

100010700
70010400

PROUUCT

composition

Mass, kg

Bulk Density, g/ce

Middle

Bollom

(whts loss in 24 h)

Mop

Bottom
Apparent Density $(g / c)$ :

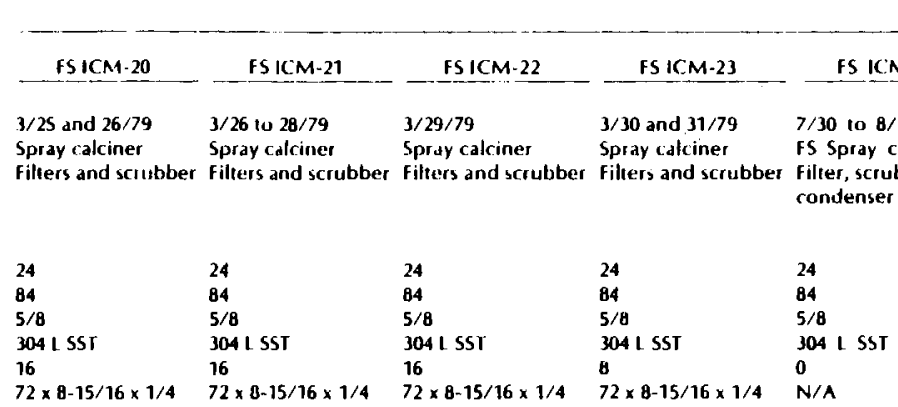

Spray calcin

27.3:727

$-20+80$

None

None

24.5
1075
1010101060

Continuous

Proportional

75
$>75$
84.4

SRI IDS
Spray colcine
$26.6: 73.2$
SRL 211
$-20,+80$
None

SRI IDS

30. 2:69.8(d)

SRL 211

$-20,+80$

None

None

28.66
1065 to 1085

1065 to 1085
1015 to 1055

Continuous

Proportional

75
$>75$

-

18.75
1065

1065
1020101055

Continuous
Proportional

85
$>85$

SRL TUS
Spray calcine
$27.8: 72.2(\mathbf{a})$
SRL 211
$-20,+80$
None

SRI TDS

Spray calcine
28:72

SRL 211
$-80,+20$

None

None

25.5
1020101060

1020101060
1020101060

Continuots

Proportional

00 (max.)

1070

Continuous

Propartional

44.6

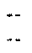

27

SRI. 10S (27:73) 211 SRI IDS (27.73) 211 SRI IDS (30.70) 211 SRI TOS (28.73) 211 SRI TDS/211

1107

(a) These are the maximum oxide and minimum frit contenis possible. The

actual contents may be closer to 28.72 , but problems with the tin additicn

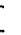

12.8

8.1
7.6
11.0

2.45
2.54
2.36
RUN NUMBER

FSICM-25

FS ICM-26

FS ICM-27

FSICM-28 - FSICM-29

9/20 to 9/21/80

$3 / 4 / 80$

356/80

$\begin{array}{ll}\text { 8/22/80 } & 8 / 25108 / 27 / 80 \\ \text { FS spray calciner } & \text { FS spray calcines }\end{array}$ Fitter, scrubber, Filter, scrubber, Fitter, scrubber. Fitter, scrubber, Filter, scrubber. condenser condenser Filter, scrubber.
condenser condenser

condenser

24
84
0.375
Inconel $601 \%$
16
$72 \times 8-15 / 16 \times 1 / 4$

24
84
$5 / 8$
304 L SSI
0

24
84
$1 / 4$

$\begin{array}{lll}24 & 24 \\ 84 & 1 / 2 & 84\end{array}$

$1 / 4$ inconel 601* $1 / 2$

$72 \times 8-15 / 16 \times 1 / 4 \quad$ N/A

N/A

84
$1 / 2$
304
0

$1 / 2$

CPP zirconia calcine

Fluidized bed calcine Spray calcin

ICPP 127

Pre-blended

SRL 211

SRL IDS moditied SRL TDS

Spray calcine Spray calcine

$-80,+20$

Cod, EDIA, Coal, EDIA, Corntlarch, coal, Cornstarch, coal,
cornstarch
cornstarch

28:72

-200 mesh $\quad-200$ mesh

cornstarch

cornstarch

Air sparge

Frit added to SC feed

32

Continuous

Pre-blended 80 (average: 48)

24

$\begin{array}{ll}19 & 16 \\ 1150 & 1070\end{array}$

$\begin{array}{llll}1060 \text { to } 1040 & 1130101150 & 1000 \text { to } 1050 & 1070 \text { 10 1070 }\end{array}$

Continuous Continuous Continuous Continuous

75 (max.)

100

102 (max.)

31

100

${ }_{80}^{130}$

85

Frii in the SC feed

78
12
55

25

PP-127

1150

SRL TDS mud./211 SRL IDS mod./211 SRL IDS/211

SRL TDS/211

$\begin{array}{llll}-. & -- & 4164 & \\ . . & . . & 2.85 & 286 \\ & - & & 2.81\end{array}$

1.90
1.67
1.59

$\ddot{-}$

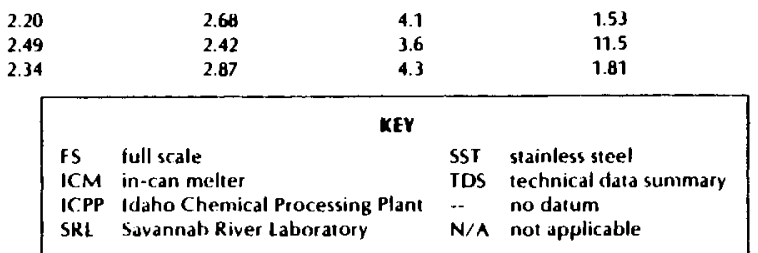


into an airlock at the desired rate. (The mixture was hand fed because it was not free flowing, and feeding problems were expected with the automatic feeders.) The hand feeding allowed for a smooth, trouble-free run. The feed rate was started at $20 \mathrm{~kg} / \mathrm{h}$ and maintained long enough to demonstrate that melting was keeping pace with the feeding. At that point the feed rate was reduced to provide an $8-h$ feed period to characterize the off-gas.

The batch could be observed through a viewport as it dropped into the canister. As batch entered the canister, its components started to separate; that is, the light ash floated to the melt surface while the powdered constituents fell very quickly. The ash ignited as it fell through the hot canister and burned the rest of the way down. The surface of the melt was difficult to see because the flames from the burning carbon obscured it. This exothermic reaction undoubtedly assisted the melting rate, but the reducing environment it created may have reduced the zinc in the glass to metal, causing a "smoke" problem as the metal vapor reoxidized in the air above the melt surface. The off-gas data collected (Tables 3 and 4 ) indicate that both methane and hydrogen were present in the off-gas, symptomatic of a reducing environment. The shortage of oxygen necessitated a long processing time to eliminate the carbon deposit at the top of the canister. After completion of the run, an 8-in. layer of carbonaceous material remained on top of the glass. ICM-30, 31,34 and 35

These four experiments were conducted to evaluate different waste solidification flowsheet options for immobilization of the high-level wastes currently stored at the Western New York Nuclear Service Center (WNYNSC), West Valley, New York.

Three flowsheet options have been investigated for vitrifying high-level wastes stored at the WNYNSC. The differences in options result from pretreatment of the waste fractions. The major chemical components of each type of waste--Tank 8D2 sludge, Tank 8D2 supernate, and Tank 804--are summarized in Table 5. Al1 three waste fractions can be converted to a high-level waste form. However, in terms of volume reduction of the final high-level waste form, it is necessary to vitrify only the radioactive portions of the waste. 
TABLE 3. Mean Off-gas Concentrations and Standard Deviations for the TRU Run

\begin{tabular}{|c|c|c|}
\hline Component & $\begin{array}{c}\text { Mean } \\
\text { Concentration } \\
g / l(a) \\
\end{array}$ & $\begin{array}{l}\text { Standard } \\
\text { Deviation }\end{array}$ \\
\hline $\mathrm{H}_{2}$ & 0.00160 & 0.000099 \\
\hline $\mathrm{CO}_{2}$ & 0.794 & 0.0767 \\
\hline $\mathrm{NO}_{x}, \mathrm{H}_{2} \mathrm{O}^{(\mathrm{b})}$ & 0.00869 & 0.00528 \\
\hline $\mathrm{O}_{2}$ & 0.0277 & 0.023 \\
\hline $\mathrm{N}_{2}$ & 0.240 & 0.056 \\
\hline CO & 0.139 & 0.069 \\
\hline $\mathrm{CH}_{4}{ }^{(\mathrm{C})}$ & 0.0183 & 0.026 \\
\hline NO & 6820 ppm & 1900 \\
\hline $\mathrm{NO}_{x}$ & 7790 ppm & 2300 \\
\hline
\end{tabular}
(a) At $100^{\circ} \mathrm{C}$ and $14.7 \mathrm{psi}$
(b) In order to calculate the concentration, the peak was assumed to be all NO
(c) A response factor for $\mathrm{CO}$ was assumed to calculate the concentration of $\mathrm{CH}_{4}$

Vitrification of the high-level waste stored at the WNYNSC can be achieved by any one of the following options:

- vitrification of the Tank 802 sludge combined with fission products recovered from the Tank 802 supernate and the acidic thorex waste in Tank 804 (Option 1)

- vitrification of the Tank 802 sludge with fission products recovered from the Tank 802 supernate separately from the vitrification of Tank 8D4 waste (Option 2)

- vitrification of the combined contents of Tanks 8D2 and 8D4 (Option 3).

The pilot-scale SC/ICM system was used to evaluate process feasibility of the waste vitrification options. Four canisters of waste glass have been produced using nonradioactive chemicals. The canisters are 8 inches in diameter 
TABLE 4. Mean Volume Percents for Each Component of the Off-Gas From the TRU Run

\begin{tabular}{lll}
\multicolumn{1}{c}{ Component } & & Mean Vol\% \\
\cline { 1 - 1 } $\mathrm{H}_{2}$ & & 2.29 \\
$\mathrm{CO}_{2}$ & & 52.1 \\
$\mathrm{NO}_{\mathrm{X}}, \mathrm{H}_{2} \mathrm{H}^{(\mathrm{a})}$ & & 0.835 \\
$\mathrm{H}_{2} \mathrm{O}^{(\mathrm{b})}$ & & 0.153 \\
$\mathrm{O}_{2}$ & & 2.50 \\
$\mathrm{~N}_{2}$ & & 24.7 \\
$\mathrm{CO}$ & & 14.3 \\
$\mathrm{CH}_{4}$ & & 3.3 \\
$\mathrm{NO}$ & & 0.682 \\
$\mathrm{NO}_{\mathrm{X}}$ & & 0.779
\end{tabular}

(a) To calculate the vol\%, the peak was assumed to be all NO

(b) To calculate the vol\% water, the following equation was used: Vol\% $\mathrm{H}_{2} \mathrm{O}=\mathrm{VO} 1 \% \mathrm{NO}_{x}, \mathrm{H}_{2} \mathrm{O}$ (from the GC) - Vol\% NO (from the $\mathrm{NO}_{x}$ monitor)

and have a fill height of 36 inches. Eighty to ninety kilograms of vitreous product is produced during a typical test.

The four canisters of glass produced represent flowsheet Option 1 (Run ICM-30), flowsheet Option 2 (Run 34) and flowsheet Option 3 (Runs 31 and 35). The production of a glass canister from flowsheet Option 3 required the use of a reducing agent. Silicon metal was added to the glass former mixture for the other canister. The purpose of the reducing agent additive was to volatilize the sulphate in the waste and improve the properties of the product.

Vitrification of Tank 802 Contents Plus Tank 804 Simulated Waste. The waste composition resulting from the blending of Tank 802 contents and Tank 804 contents (Option 3) has high concentrations of sodium, nitrate, nitrite, and sulphate. The sulphate composition dominates the waste characteristics due to 
TABLE 5. Chemical Composition of Neutralized High-Level Waste Stored in Tank 802 and Acidic Waste Stored in Tank $804(a)$, mole/liter

\begin{tabular}{|c|c|c|c|}
\hline Component & $\frac{\text { Neutral Wa }}{\text { Supernate }}$ & $\frac{\text {, Tank } 802}{\text { STudge(b) }}$ & $\begin{array}{l}\text { Acidic Waste } \\
\text { Tank } 804 \\
\end{array}$ \\
\hline Al & 0.01 & $0.09(1.8)$ & 0.35 \\
\hline $\mathrm{Cr}, \mathrm{Ni}$ & N. A. & $0.04(0.08)$ & N.A. \\
\hline $\mathrm{Fe}$ & N. A. & $0.29(5.8)$ & N.A. \\
\hline $\mathrm{Na}, \mathrm{K}$ & 6.78 & N.A. & N.A. \\
\hline Th & N.A. & N.A. & 1.46 \\
\hline $\mathrm{Cl}$ & 0.01 & N.A. & 0 \\
\hline$F$ & 0.01 & N.A. & 0.1 \\
\hline$P$ & 0.08 & N.A. & 0.04 \\
\hline $\mathrm{SO}_{4}$ & 0.28 & N.A. & N.A. \\
\hline $\mathrm{HNO}_{3}$ & N.A. & N.A. & 1.03 \\
\hline Curies, Total (1973) & $4.0 \times 10^{7}$ & $2.7 \times 10^{8}$ & $2.5 \times 10^{6}$ \\
\hline Volume, Gallon & 570,000 & 30,000 & 12,000 \\
\hline $\begin{array}{l}\text { Self-heating valve } \\
\text { (Btu/h/gal) }\end{array}$ & & & \\
\hline
\end{tabular}

(a) Reference: TID-28905-2

(b) Numbers in parentheses are based on wet sludge volume N.A. Not applicable

its large relative volume and high chemical content. The sodium concentration in the actual waste formed from blending Tank 802 and Tank 804 would be approximately 6.5 molar. The waste composition was diluted in experimental tests to lower the solids loading in the spray calcine feed, making the waste processable in the experimental system. This lowered the sodium concentration from 6.5 to 4.0 molar. The ratio of sodium to all other cations in this waste is approximately twenty to one. Calcine resulting from this feed mixture melts in the temperature range 350 to $400^{\circ} \mathrm{C}$ primarily because of the high sodium concentration. The calciner was operated at a temperature of 350 to $400^{\circ} \mathrm{C}$ to prevent sintering of calcine on the calciner walls. This operating method results in incomplete calcination of the waste feed materials. 
Inspection of the calciner barrel after both tests showed no visible buildup of sintered calcine. The feed processing rate in each test was $30 \mathrm{l} / \mathrm{h}$, producing a glass product at a rate of $10 \mathrm{~kg} / \mathrm{h}$. The run was completed without any process or equipment problems.

Silicon metal and graphite were used as reducing agents to volatilize sulphate in the production of the first and second canisters, respectively. The reducing agents were added on a three-to-one molar basis with the sulphate ion. The weight percent sulphate removal was approximately $89 \%$ with silicon metal as a reducing agent and approximately $30 \%$ with graphite as a reducing agent. Visual inspection of the canister wall revealed extensive corrosion when silicon metal was added as the reducing agent. This corrosion can be controlled by reducing the silicon metal addition rate. Sodium sulphate phase separation was not noticeable in either canister of glass.

Leach test results reported as weight percent lost and volume percentage crystallinity of the glass in which silicon was used as the reducing agent is summarized in Table 6 . The standard Soxhlet leach test was conducted over a 24-h period in $100^{\circ} \mathrm{C}$ deionized water. The $\mathrm{pH}-4$ leach test was conducted using a sodium-acetate buffered acetic acid solution at room temperature for $19 \mathrm{~h}$. The difference in results between the laboratory and pilot-plant data reflects primarily the difference in waste calcine loading in the glass. The presence of crystals in the glass indicates the formation of one or more separate crystalline phases, which has not been identified. Selected physical properties of the glass are also summarized in Table 6 .

The glass former mixture for flowsheet Option 3 did not contain any alkali material $\left(\mathrm{Na}_{2} \mathrm{O}, \mathrm{K}_{2} \mathrm{O}\right)$. As a result, the glass formers do not melt at in-can melter processing temperatures of 1020 to $1050^{\circ} \mathrm{C}$. The sodium oxide in the calcined waste is a necessary component to make a durable and processable glass. The relatively good leach results of the pilot-plant glass reflect the ability of the waste calcine to become soluble in the glass former mixture.

Vitrification of Tank 802 Sludge, Recovered Fission Products and Tank 804 Simulated Waste. A third canister of nonradioactive waste glass was produced using the flowsheet for Option 1. The waste composition resulting from this flowsheet has a high solids content. The simulated waste was diluted by 
TABLE 6. Physical Characteristics of Laboratory and Pilot-Plant Glasses (Tanks 802 and 804 Waste) with Silicon Metal Added as Reducing Agent

\begin{tabular}{|c|c|c|}
\hline & $\begin{array}{r}\text { wt\% } \\
\text { Through } \\
\text { Soxhlet }\end{array}$ & $\begin{array}{l}\text { ost } \\
\text { eaching } \\
\frac{\mathrm{nH} 4}{4}\end{array}$ \\
\hline Type of Glass & Soxhlet & \\
\hline Laboratory & 8.0 & 0.5 \\
\hline Pilot-Plant & 3.3 & 2.2 \\
\hline
\end{tabular}
(a) Physical Properties: Crystallinity $7 \%$ Specific Heat $\quad 0.18$ to 0.22 (cal/gram) $\quad\left(100-450^{\circ} \mathrm{C}\right)$ Thermal Expansion $1.12 \times 10^{-5}$ Softening Point Temperature $\quad 535^{\circ} \mathrm{C}$ in. $/^{\circ} \mathrm{C}\left(100-400^{\circ} \mathrm{C}\right)$

a factor of 15 from the flowsheet to make the liquid waste pumpable in the pilot-plant feed system. The spray calciner feed rate for the test averaged $27 \mathrm{l} / \mathrm{h}$, corresponding to a glass production rate of $10 \mathrm{~kg} / \mathrm{h}$. Glass formers were added as premelted frit but with a size range of -20 to +80 mesh.

The glass produced in the pilot plant has a leach rate greater than the laboratory glass, because waste loading in the glass was higher than expected. Spine 1 was not present in the glass. The glass product was homogeneous, and no separate phases were identified.

Calciner operating temperatures for this experiment were 700 to $750^{\circ} \mathrm{C}$. This higher temperature of operation increases the spray calciner feed capacity. The higher operating temperature of the calciner can be achieved because of the higher melting point of the calcine (approximately $100^{\circ} \mathrm{C}$ ). Leach test results and selected physical properties are summarized in Table 7.

Vitrification of Tank 802 Alkaline Sludge and Recovered Fission Products. A second canister of nonradioactive waste glass was produced using a simulated waste representative of the alkaline waste resulting from flowsheet Option 2. The glass composition for this waste is very similar to the glass from flowsheet Option 1 . 


\section{TABLE 7. Physical Characteristics of Laboratory and Pilot-P lant Glasses (Tank 802 Neutral Sludge and Tank 804 Thorex Waste)}

\begin{tabular}{|c|c|c|}
\hline & $\begin{array}{r}\text { wt } \\
\text { Through }\end{array}$ & \\
\hline Type of Glass (a) & Soxhlet & $\overline{\mathrm{pH} 4}$ \\
\hline Laboratory & 2.5 & 0.5 \\
\hline Pilot-Plant & 9.1 & 10.1 \\
\hline
\end{tabular}

(a) Physical Properties:

$\begin{array}{ll}\text { Crystallinity } & \text { No spinel present } \\ \text { Specific Heat } & 0.18 \text { to } 0.25 \\ \quad(\text { cal/gram }) & \left(100 \text { to } 450^{\circ} \mathrm{C}\right) \\ \text { Thermal Expansion } & 9.92 \times 10^{-6} \text { in. } .{ }^{\circ} \mathrm{C} \\ & \left(100 \text { to } .400^{\circ} \mathrm{C}\right) \\ \text { Softening Point } & \\ \text { Temperature } & 525^{\circ} \mathrm{C}\end{array}$

Leach test results for the pilot-plant glass produced are summarized in Table 8 . These leach test results are compared to the borosilicate glass, 76-68, which demonstrates good physical and chemical properties. Leach test results for all pilot-plant glasses are comparable to the referenced glass. The leach rate of the pilot-plant glasses can be improved with the appropriate glass former modifications.

This study demonstrated that the spray calciner/in-can melter process can produce a high quality glass product from the three flowsheet options considered for the immobilization of the high-level waste stored at West Valley, New York. The glass products produced from the three flowsheet options compare with the chemical durability of a well-developed reference borosilicate glass. $\underline{\text { ICM-32 }}$

This run was performed to investigate possible processing problems with fluidized bed calcine from the Idaho Chemical Processing Plant (ICPP) waste (Bjorklund et al. 1980). The calcine contains a large amount of fluorine, which is extremely corrosive. The calcine is made up of course-fraction, fluid-bed granulars and a fine fraction collected from off-gas filters. The fine fraction presented potential materials handling and melter plugging prob- 
TABLE 8. Leach Test Comparison--Tank 802 Neutral

Sludge and Recovered Fission Products

with Borosilicate Glass 76-68

Type of Glass

Pilot-Plant

76-68

\begin{tabular}{|c|c|}
\hline$\frac{w t \%}{h}$ & $\frac{\mathrm{t}}{\mathrm{DH}}$ \\
\hline 5. & 1.2 \\
\hline 1.6 & 0. \\
\hline
\end{tabular}

lems. The glass formers were blended with the calciner as a pre-melted frit and then fed to the melter with a gravimetric feeder.

Feeding the mixture of course calcine and frit together with the fine calcine presented few feeding problems. The powder did tend to stick to the sides of the canister and at the feed pipe, but no interruptions in the run were necessary. Indications of overfeeding the canister did interrupt the process once, but the melter recovered very quickly and melted all of the batch. Batch accumulation and a dropping center-line temperature indicated that the inventory of unmelted batch was increasing. The center-line temperature dropped $300^{\circ}$ to $400^{\circ} \mathrm{C}$, which is much greater than the normal decrease of $100^{\circ}$ to $300^{\circ} \mathrm{C}$.

To monitor the action of the fluoride present in the calcine, stainless steel corrosion coupons were hung inside the off-gas tube. Inspection of the coupons revealed no corrosion to the coupons. There was no weight loss and no evidence of a film forming or of any deterioration of sharp edges or corners. The coupons were just above the canister and about $2 \mathrm{ft}$ higher in the off-gas line. General corrosion of the canister by the glass was evident by the films formed on all contact surfaces.

The glass was predominantly green and contained traces of red, yellow, and blue. Analys is of the glass showed no significant composition differences. The glass was extremely durable and contained approximately $10 \%$ dentrite crystals (CaF), which did not affect product quality.

$\underline{\text { ICM-33 }}$

To supplement full-scale melter studies, in support of Savannah River's defense waste processing facility, the SRL flowsheet was modified to include anthracite coal and tetrasodium ethylene diamine tetraacetic acid ( $\mathrm{Na}_{4}$ EDTA) 
for the spray calciner/in-can melter run. Both of these constituents are present in the waste but may or may not end up in the vitrification stream. The purpose of the run was to evaluate the effect of these constitutents on processing. It had been shown in laboratory tests that a reducing environment produced by burning these organic chemicals could reduce the foaming tendency of the Savannah River glass. But the demonstration was needed to show that the organics would not be consumed in the calciner, and that other unacceptable processes would not occur.

The run demonstrated that the organic material could be successfully sent through the spray calciner and decomposed in the in-can melter. Sparks and flame were visible from the viewport on the canister, and lower oxygen levels were detected in the off-gas. The effect of the reducing chemicals could not be determined because of feed makeup problems that contributed to the making of a nontypical product. Organic chemicals were also used in the full-scale apparatus, FS-ICM 26.

\section{$\underline{\text { ICM-36 }}$}

To improve processing and product quality, powdered ( -200 mesh) frit was added to spray-calciner feed to improve the blend of frit with calcine. This type of feed put severe limits on the spray calciner, which limited the melting rate to $5 \mathrm{~kg} / \mathrm{h}$. Even at this slow feed rate, the melt surface was obscured from view by a fog caused by the cornstarch, coal, and sodium-EDTA. Only $1 \mathrm{ft}$ of glass was produced, but it was sufficient to prove the concept for trial in a full-scale canister. Although the intimately mixed frit and calcine, together with the organics, cornstarch, coal, and EDTA (which were part of the feed stock and not additives), were supposed to improve product quality, the glass exhibited the same concentration gradients and crystallinity as unmixed batch.

\section{FULL-SCALE MELTER}

Process runs FS-ICM-20 through 29 were performed in the full-scale ICM. 
FS-ICM-20 to 23

Four full-scale canisters were filled during a continuous, 5-day run of the full-scale SC/ICM system. At this time, a connecting section, which was constructed to demonstrate remote canister change out, was used to facilite the exchange of hot, 24-in.-diameter canisters. The run was completed for SRL using TDS waste and 211 frit. The first three canisters had 16 plate assemblies for heat transfer; the last canister processed had only eight fins. The run was mared by frequent plugging problems of the spray calciner nozzles due to the solids content of the SRL feed slurry.

The connecting section (Petkus, Gorton, and Blair 1981) was first demonstrated during this run. The unit allowed the change out of the four canisters only with some difficulty. After the first canister was filled, the interlocking tube arrangement collected calcine in the spout expansion bellows (Figure 4), restricting bellows retraction. As calcine collected, it became more difficult to operate the spout lifting device. The connecting section had no other problems except that it did become plugged when the spray calciner nozzle broke, allowing wet calcine into the connecting section.

The average processing rate for the four canisters was $45 \mathrm{~kg} / \mathrm{h}$, including $98 \mathrm{~h}$ of run time over the 5 days. Canister change out is not included because the SC/ICM system would normally have two furnaces for continuous operation. The rates among the various runs differ mostly because of continuing nozzle plugging problems. Also, the melting rate was sometimes limited by the spray calciner. The eight-fin canister had an average rate of $45 \mathrm{~kg} / \mathrm{h}$ and a peak rate of $80 \mathrm{~kg} / \mathrm{h}$. This was considered near maximum for the feed, canister size, and number of fins. The peak rate for the canisters with 16 fins was $85 \mathrm{~kg} / \mathrm{h}$. Me1t temperatures indicated that higher rates could have been achieved.

The furnace's power monitoring system was upgraded for this run. More sensitive power monitors were used and these were tied to a continuous recorder to monitor power to each zone. The monitors revealed that balance between the furnace temperature controllers was not good and that certain zones were carrying the bulk of the load. The SCR biases were adjusted to even out the load. As expected, the top and bottom zones drew more power than the other zones even after the adjustments. 


\section{FS-ICM-24}

This test was made for SRL to determine whether or not a satisfactory product can be obtained at an acceptable rate by in-can melting without internal fins. Run ICM-24 is a continuation of the 5-day run in which 24-in.-diameter canisters were used with 16- and 8-plate assemblies. SRL waste, TOS, and frit 211 were used in the tests. Although maximum rate data were desired, indications are that the $60-\mathrm{kg} / \mathrm{h}$ rate demonstrated was not the maximum rate attainable. Even $60 \mathrm{~kg} / \mathrm{h}$ was higher than expected, based on earlier work on 8-in.diameter canisters. This high rate may be due to the greater convection possible in a larger canister.

The ICM power recording system allowed balancing the load among the zones in the furnace. When the load was initially balanced, with zones 1 and 6 higher because of end losses, the load shifted as the melt level rose in the canister. The power necessary to hold the melter at temperature was $45 \mathrm{~kW}$, and the power used to melt at $60 \mathrm{~kg} / \mathrm{h}$ was 60 to $65 \mathrm{~kW}$.

Progress in the in-can melter was also followed by Hastelloy $x^{\circledR}$-sheathed thermocouples located in the canisters. Earlier failures with stainless steel sheaths were traced to corrosion of the sheaths by the frit, which is quickmelting and can exist in locally high concentrations. This problem was reduced by shifting to the more resistant alloy.

FS-ICM-25

The demonstration of vitrification of ICPP waste (Bjorklund et al. 1980) in the pilot scale melter, ICM-32, provided answers to several questions. However, a full-scale run was also needed to provide extra information on the process requirements. The test was made in a 24-in.-diameter Incone ${ }^{\circledR} 601$ canister to eliminate any product changes due to the corrosion products of stainless steel. The full-scale test also gives a much more complete picture of materials handling problems.

The 24-in.-diameter by 7-ft can was filled at a peak rate of $80 \mathrm{~kg} / \mathrm{h}$. This rate was sustained for over $3 \mathrm{~h}$. The average feedrate during the run was

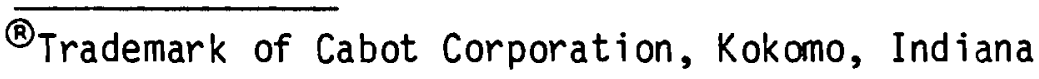


$48 \mathrm{~kg} / \mathrm{h}$. Although the run proceeded without incident, when the canister was disconnected from the connecting section, it was found to be heavily coated with calcine and frit. Different blends of the two constituents were found in different sections of the pipe. This is believed to be due to differing conditions in the pipe, to high-temperature melting near the canister, and to condensation of water vapor.

The product quality for the two runs was very similar. The compositions of the two tests were similar and the leach rates were nearly identical. The pilot-scale test produced a much more colorful glass, while the full-scale glass was dull green with some red streaks. The reasons for the differences have not been explained. It was thought that corrosion products from the stainless steel affected the glass, but laboratory melts in platinum crucibles also produced multicolored glasses.

The off-gas from the melter was sampled during the run. The constituent of concern was the fluoride ion. Background concentrations of fluoride were 50 parts per billion (ppb) in the caustic scrub solutions. No increase was detected during the run. Shortly after this run, the spray calciner filters showed evidence of severe corrosion. The corrosion could not be shown to come from fluoride attack.

FS-ICM-26 and 27

The primary objective of Runs 26 and 27 was to compare the filling of canisters at different operating temperatures but under otherwise identical conditions. The canisters were filled with Savannah River Laboratory (SLR)type glass. The waste composition was TDS waste modified to include anthracite $\mathrm{coa} 1, \mathrm{Na}_{4}$ EDTA, and cornstarch. These chemicals are part of the current waste flowsheet at SRL.

The filling of the canisters provided some interesting results. Very high melting rates were achieved, apparently due to the large amount of carbon in the feed. Burning of the organic material was observed through the viewport. Occasional pressurization of the canisters was evident when blowback or vibration caused large quantities of calcine or frit to enter the canister. The carbon caused metallic deposits on the bottom of the canisters. The deposits were identified as nickel subsulfide, $\mathrm{Ni}_{3} \mathrm{~S}_{2}$. 
According to plan, each canister was to be filled at $75 \mathrm{~kg} / \mathrm{h}$. Although differences in fill height would probably result from a greater foam layer buildup in the slower canister, no rate adjustments were to be made. Any overfeed condition would thus be manifested as foam. The first canister (the cooler of the two) was run at $1075^{\circ} \mathrm{C}$ and was filled with little or no evidence of foam. The final level was 22 in. below the top of the canister (about 11 in. below the $100 \%$ full point), probably due to foam and some shrinkage of the glass. Because of this success at $1075^{\circ} \mathrm{C}$, the next canister, run at $1150^{\circ} \mathrm{C}$, had to be filled at a higher rate to show any difference in performance. One hundred kilograms per hour was picked as the rate for this canister. Unfortunately, problems with auxiliary equipment prevented a controlled fill of the second canister, and no direct comparison can be made. Since neither of the rates appeared to tax the melter capabilities, higher rates could probably be achieved for both canisters. Power usage decreases as the canister fills up. Figures 5 and 6 illustrate both weight increase and power as a function of time for each canister. The plots show no relation between the weight of fill and the power. This indicates that either the melter was under-utilized or that a new mechanism for power input has taken over with the modified feed. If the melter was under-utilized, it could have used more power and melted more glass. A new mechanism could include mixing in the canister, allowing for more heat transfer and a higher power input. This phenomenon bears further investigation, as the canisters without fins had the same rate as canisters with 16 fins.

Neither canister had a continuous fill, because several problems were encountered with the frit delivery system. During the same period of time, it was recognized that there was a leak at the frit airlock. That is, the lower valve was not seating and allowing air to bleed through when the top valve was open. The valve was adjusted to seal, and this adjustment in turn required an adjustment to the 1 imit switch arm. This incident caused a shutdown of four hours. Fortunately, the problems occurred in the early part of the run and did not affect the more significant rate demonstration at the top of the can.

During the second canister filling, the limit switch arm adjustment again failed. The limit switch was not tripped, which prevented the upper valve 


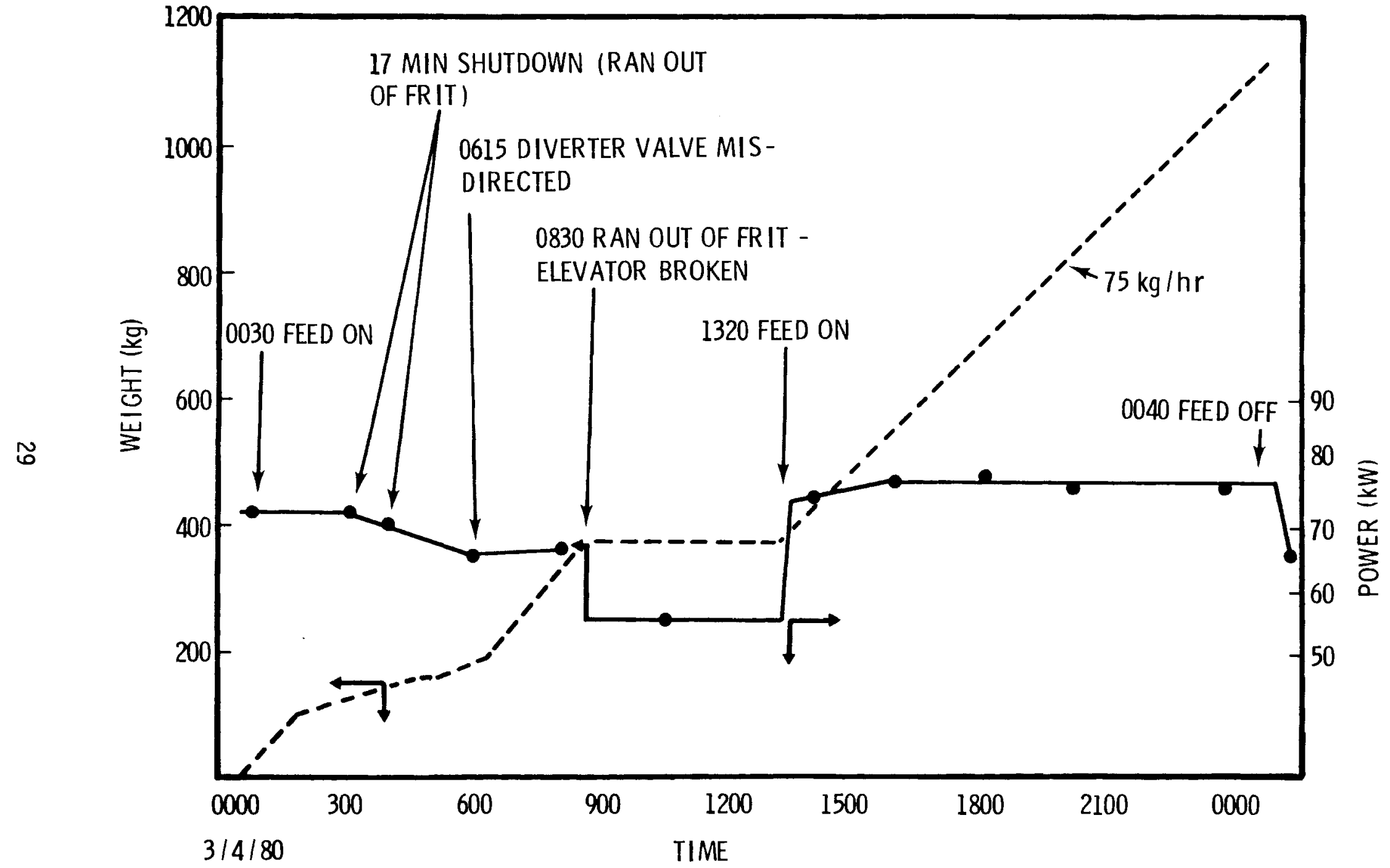

FIGURE 5. Time Summary FS-ICM-26 (SRL - No Fins) 


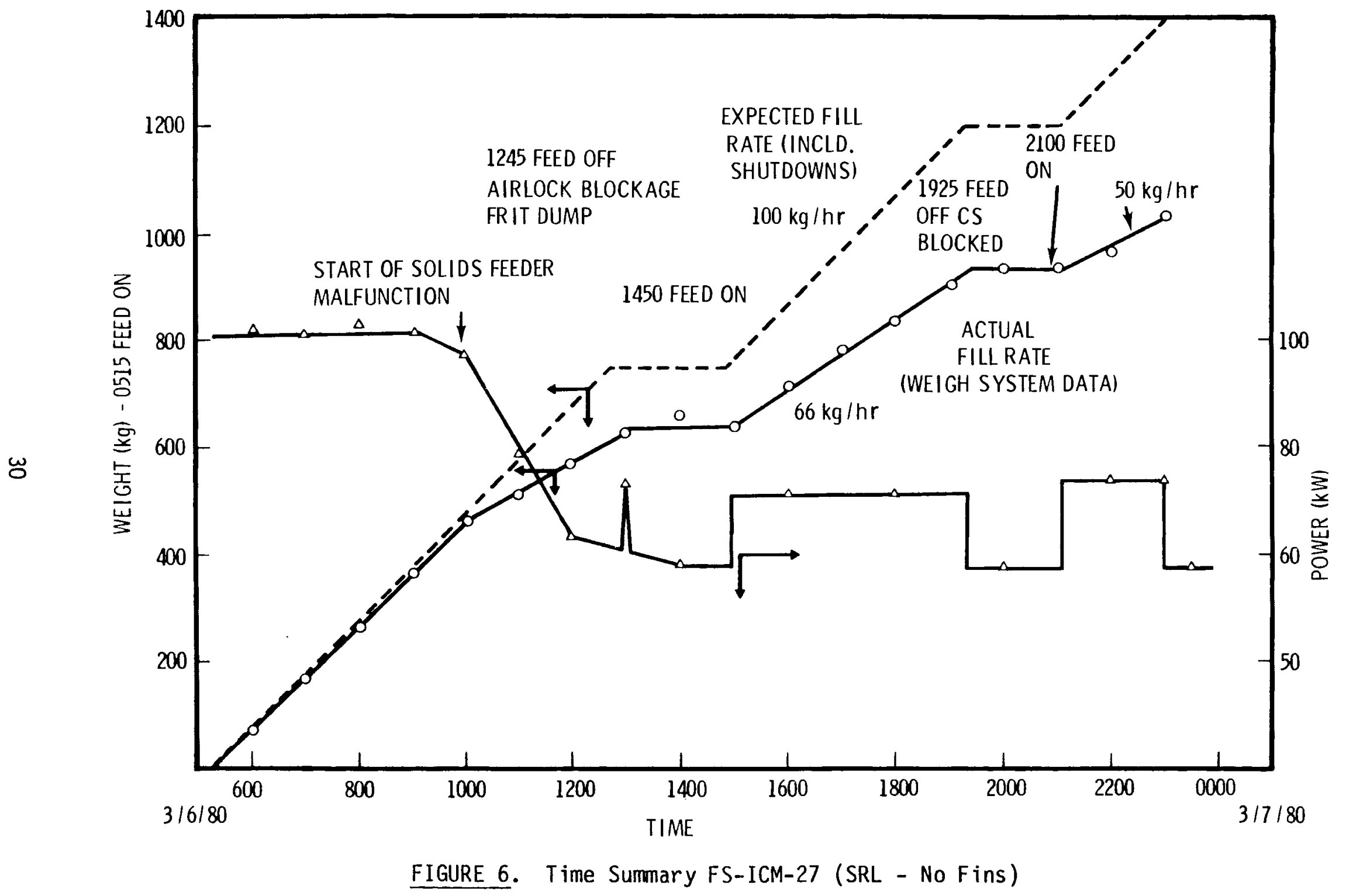


from operating. Since the valve did not operate, the frit backed up into the solids feeder. The lower valve was readjusted and the feeder was cleaned out. In addition, a photo ce 11 connected with the belt speed transducer malfunctioned. The belt speed seemed to move faster than it really was and cut the frit addition to as much as $1 / 3$ of the normal rate. The circuitry problem was not identified during the run, but the effects are clearly shown in the canister weight and power plot for canister FS-ICM-27. The value of timely use of these data is obvious, but the data must be converted to a more usable form.

The ICM remote connecting section was used during the March SC/ICM run. However, at the startup of the second high-temperature canister, the remote connecting section was replaced by the old connecting section. The cone valve on the remote connecting section lost cooling capability and overheated due to a plug in the exit fitting. The cone-valve-thermocouple temperatures increased rapidly to approximately $1100^{\circ} \mathrm{C}$, and the steam pressure caused a separation of the weld seam on the bottom plate.

The weigh system did not perform as hoped during the run. The first canister had some expansion/interference problems, which caused faulty readings from the load cells. The second canister was free and gave weight data which helped interpret the frit feeder problems described above. The rate of the we ight ga in system did not give any usable data.

FS-ICM-28 and 29

This pair of runs was completed to compare two mixing methods against themselves and against the nonmixed case. The nonmixed case includes coordinated dumping of frit to match the periods of heaviest calcine dumping, such as when the filter elements are blown back. The two mixing methods tested were 1) air sparging the glass, and 2) premixing powdered frit in the spray calciner feed stream.

Run FS-ICM-28 filled the canister in a similar manner to FS-ICM-26 except that a sparge was added to the canister. Both tests were intended to be ratedetermining runs for the TDS Frit-211 composition using canisters without fins in the SC/ICM system. The experimental plan called for filling the entire canister at one rate and stopping the fill when foam or glass reached the top 
of the thermocouple tree, which is $11 \mathrm{in}$. from the top of the canister. FSICM-26 was run at $75 \mathrm{~kg} / \mathrm{h}$ and gave every indication that higher rates could be achieved. FS-ICM-28 was run at $85 \mathrm{~kg} / \mathrm{h}$, and the canister was filled equally well. Indications from the power usage show that this rate is close to limiting at the top of the canister; however, faster fill rates could be achieved in the bottom two-thirds of the canister. Overall, the sparging does not appear to affect the melting rate.

At the end of the run, the air flow to the sparger was increased to increase the mixing action. The glass agitation was increased and successfully pulled down most of the clinkers that were present at the top of the canister. This did not give a clean top on the cooled canister because material spalled off the sides. The top was clean and smooth after the canister was vacuumed out. The canister was sparged at the high flow rate for $45 \mathrm{~min}$, then the sparger and ICM furnace were turned off for cool-down.

Run FS-ICM-29 filled the canister with a calcined slurry that contained powdered frit. Because of the low stick point of the frit, the calciner barrel temperature was held to $400^{\circ} \mathrm{C}$. This barrel temperature restriction limited the production rate to approximately $17 \mathrm{~kg} / \mathrm{h}$. The low rate should have assisted in the mixing, because the calcine melts as it is added, and the melted glass has a long "soak" time at $1070^{\circ} \mathrm{C}$ during the time the rest of the canister is being filled. Convection should be minimized because of the isothermal condition of the canister. The slow rate seemed to defeat the normal methods for monitoring the fill rate. Because of the difficulty in tracking the fill rate satisfactorily, the canister was not filled completely. This did not affect the results.

Composition, leach rate, and crystallinity were all measured from the canister core samples. They are notable only in their lack of change from earlier ICM canisters. The large concentration gradients and crystallinity are indistinguishable, meaning that either the mixing only approximated the level of natural mixing in the canister and that much greater mixing is necessary to achieve a homogeneous product, or that the gradients could be formed by crystal formation and collection motivated by convection currents in the glass. The vigorous sparge mixing of canister contents in FS-ICM-28 at the 
end of the that run made it appear to the observer that the canister was wellmixed, but the viscous spinel sludge could have resisted all attempts at agitation. 


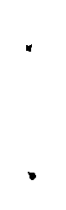




\section{REFERENCES}

Blair, H. T. 1979. In-Can Melting Process and Equipment Development From 1974 to 1978. PNL-2925, Pacific Northwest Laboratory, Richland, Washington.

Bjorklund, W. J., et a1. 1980. In-Can Melting Demonstration of Wastes From the Idaho Chemical Processing PTant. PNL-3405, Pacific Northwest

Laboratory, Richland, Washington.

Bonner, W. F., et al. 1976. Spray Solidification of Nuclear Waste. BNWL-2059, Pacific Northwest Laboratory, Richland, Washington.

Elliot, M. N., et al. 1960. Report of Second Working Meeting of Fixation of Radioactivity in Stable Media. TID 7613, Idaho Falls, Idaho.

Grover, J. R., et al. 1966. The FINGAL Process. AERE-R5188, United Kingdom Atomic Energy Authority, Chemical Engineering Division, Harwell, Bershire, UK.

Holton, L. K., D. E. Larson, G. B. Mellinger, T. A. Nelson. 1980. "Alternatives for Vitrification of Existing Commercial High-Level Waste by Spray Calcination/In-Can Melting." PNL-SA-8241, presented at "Waste Management 80," Tucson, Arisonz, March 10-14, 1980.

Larson, D. E., Editor. 1980. Spray Calciner/In-Can Melter High-Level Waste Solidification Technical Manual. PNL-3495, Pacific Northwest Laboratory, Richland, Washington.

Lucas, J. M., L. L. Petkus, G. B. Mellinger. 1981. Evaluation of DefenseWaste Glass Produced by Full-Scale Vitrification Equipment. PNL-3550, Pacific Northwest Laboratory, Richland, Washington.

MCElroy, J. L., et al. 1972. "Waste Solidification Program Summary Report. In Volume 2 of Evaluation of WSEP High-Level Waste Solidification Processes. BNWL-1667, Pacific Northwest Laboratory, Richland, Washington.

Mellinger, G. B., C. R. Palmer, L. L. Petkus. 1979. "Vitrification of TRU Incinerator Ash." Paper presented at the Joint Fall Meeting of the Basic Science and Nuclear Divisions of the American Ceramic Society, October 14-17, 1979, New Orleans.

Ross, W. A., et a1. 1978. Annual Report on the Characterization of High-Level Waste Glasses. PNL-2625, Pacific Northwest Laboratory, Richland, Washington.

Petkus, L. L., P. S. Gorton, H. T. Blair. 1981. Connecting Section and Associated System Concept for the In-Can Melter Process. PNL-3170, Pacific Northwest Laboratory, Richland, Washington. 
. - 


\section{DISTRIBUTION}

No. of

Copies

OFFSITE

A. A. Churm

DOE Chicago Patent Group

9800 South Cass Avenue

Argonne, IL 60439

R. Y. Lowrey

DOE Albuquerque Operations Office

P.0. Box 5400

Albuquerque, NM 87185

A. L. Taboas

DOE Albuquerque Operations Office

P.0. Box 5400

Albuquerque, NM 87185

S. A. Mann

DOE Chicago Operations and Region Office

Argonne, IL 60439

J. 0. Neff

Department of Energy

Columbus Program Office

$505 \mathrm{King}$ Avenue

Columbus, $\mathrm{OH} 43201$

W. E. Mott

DOE Division of Environmental Control Technology

Washington, DC 20545

J. P. Hamric

DOE Idaho Operations Office

550 2nd St.

Idaho Falls, ID 83401

J. W. Peel

DOE Idaho Operations Office

550 2nd St.

Idaho Falls, ID 83401
No. of

Copies

J. B. Whitsett

DOE Idaho Operations office

550 2nd St.

Idaho Falls, ID 83401

S. Vorndron

DOE Idaho Operations Office

550 2nd St.

Idaho Falls, ID 83401

C. R. Cooley

DOE Nuclear Waste Management Programs

NE-331, GTN

Washington, DC 20545

G. H. Daly

DOE Nuclear Waste Management Programs

NE-322, GTN

Washington, DC 20545

J. E. Dieckhoner

DOE Nuclear Waste Management Programs

NE-321, GTN

Washington, DC 20545

C. H. Goerge

DOE Nuclear Waste Management

Programs

NE-330, GTN

Washington, DC 20545

C. A. Heath

DOE Nuclear Waste Management Programs

NE-330, GTN

Washington, DC 20545

M. L. Lawrence

DOE Nuclear Waste Management Programs

NE-340, GTN

Washington, DC 20545 
No. of

Copies

D. J. McGoff

DOE Nuclear Waste Management Programs

NE-320, GTN

Washington, DC 20545

S. Meyers/R. Romatowski

DOE Nuclear Waste Management Programs

NE-30, GTN

Washington, DC 20545

G. Oertel

DOE Nuclear Waste Management Programs

NE-320, GTN

Washington, DC 20545

A. F. Perge

DOE Nuclear Waste Management

Programs

NE-30, GTN

Washington, DC 20545

R. W. Ramsey, Jr.

DOE Nuclear Waste Management

Programs

NE-301, GTN

Washington, DC 20545

V. Trice

DOE Nuclear Waste Management Programs

NE-30, GTN

Washington, DC 20545

D. L. Vieth

DOE Nuclear Waste Management Programs

NE-332, GTN

Washington, DC 20545

S. W. Ahrends

DOE Oak Ridge Operations Office

P.0. Box E

Oak Ridge, TN 37830
No. of

Copies

D. E. Large

DOE Oak Ridge Operations Office P.0. Box E

Oak Ridge, TN 37830

S. G. Harbinson

DOE San Francisco Operations Office

1333 Broadway

Oakland, CA 94612

W. B. Wilson

DOE Savannah River Operations Office

P.0. Box A

Aiken, SC 29801

R. P. Whitfield

DOE Savannah River Operations Office

P.0. Box A

Aiken, SC 29801

W. W. Bixby

Department of Energy

P.0. Box 88

Middletown, PA 17057

J. B. Martin

Division of Waste Management

Nuclear Regulatory Commission

Washington, DC 20555

D. B. Rohrer

Division of Waste Management Nuclear Regulatory Commission Washington, DC 20555

R. D. Smith

Division of Waste Management Nuclear Regulatory Commiss ion Washington, DC 20555 
No. of

Copies

R. E. Cunningham

Office of Nuclear Safety

Materials and Safeguards

Nuclear Regulatory Commission

Room 562, 7915 Eastern Avenue

Silver Springs, MD 20910

27 DOE Technical Information Center

J. A. Buckham

Allied-General Nuclear Services

P.0. Box 847

Barnwe 11, SC 29812

A. Williams

Allied-General Nuclear Services

P.0. Box 847

Barnwe 11, SC 29812

J. H. Kittel

Argonne National Laboratory

Office of Waste Management Programs

9700 South Cass Avenue

Argonne, IL 60439

M. J. Steindler/L. E. Trevorrow

Argonne National Laboratory

9700 South Cass Avenue

Argonne, IL 60439

W. Carbiener

Battelle Memorial Institute

Office of Nuclear Waste Isolation

505 King Avenue

Columbus, $\mathrm{OH} 43201$

Beverly Rawles

Battelle Memorial Institute

Office of Nuclear Waste Isolation

505 King Avenue

Columbus, $\mathrm{OH} 43201$

Research Library

Battelle Memorial Institute

$505 \mathrm{King}$ Avenue

Columbus, $\mathrm{OH} 43201$
No. of

Copies

R. Maher, Program Manager

Waste Management Programs

Savannah River Plant

E. I. Du Pont de Numours \& Co.

Aiken, SC 29801

M. D. Boersma

E. I. Du Pont de Numours \& Co. Savannah River Laboratory

Aiken, SC 29801

R. G. Garvin

E. I. Du Pont de Numours \& Co.

Savannah River Laboratory

Aiken, SC 29801

D. L. McIntosh

E. I. Du Pont de Numours \& Co. Savannah River Laboratory

Aiken, SC 29801

A. L. Ayers

$E G$ \& $G$ Idaho

P.0. Box 1625

Idaho Falls, ID 83415

R. Williams

Electric Power Research Institute

3412 Hillview Avenue

Palo Alto, CA 94304

Environmental Protection Agency

Technological Assessment

Division (AW-559)

Office of Radiation Programs

U.S. Environmental Protection Agency

Washington, DC 20460

J. R. Berreth

Exxon Nuclear Idaho

P.0. Box 2800

Idaho Falls, ID 83401

G. L. Ritter

Exxon Nuclear Idaho

P.0. Box 2800

Idaho Falls, ID 83401 
No. of

Copies

J. Campbe 11

Lawrence Livermore Laboratory

P.0. Box 808

Livermore, CA 94550

R. Roy

202 Materials Research

Laboratory

Pennsylvania State University

University Park, PA 16802

A. L. Lotts

Oak Ridge National Laboratory

P.0. Box X

Oak Ridge, TN 37830

A. B. Martin

Rockwe 11 International

Energy Systems Group

8900 DeSoto Avenue

Canoga Park, CA 91304

Paul Hagen

Chemical Operations

Rockwe 11 International

Rocky Flats Plant

P.0. Box 464

Golden, CO 80401

E. Vejvoda, Director

Chemical Operations

Rockwe 11 Internationa 1

Rocky Flats Plant

P.0. Box 464

Golden, CO 80401

R. G. Kepler

Organic and Electronic Dept. 5810

Sandia Laboratories

Albuquerque, NM 87185

P. B. Macedo

Keane $\mathrm{Ha} 11$

Vitreous State Laboratory

The Catholic University of America Washington, DC 20017
No. of

Copies

L. L. Hench

Dept. of Materials Science and Engineering

University of Florida

Gainesville, FL 32611

Dr. Hayne Palmour III

2140 Burlington Engineering Laboratories

North Carolina State University

Raleigh, NC 27607

ONSITE

4 OOE Richland Operations Office

R. E. Gerton

H. E. Ransom

J. J. Schreber

M. W. Shupe

4 Rockwell Hanford Operations

I. E. Reep

D. D. Wodrich (3)

UNC United Nuclear Industries

F. H. Bouse

Westinghouse Hanford Company

A. G. Blasewitz

37 Pacific Northwest Laboratory

W. J. Bjorklund

W. F. Bonner

D. B. Cear lock

T. D. Chikalla

J. W. Finnigan

C. R. Hann

A. J. Haverfield

J. H. Jarrett

D. E. Knowlton

C. A. Knox

L. T. Lakey 
No. of

Copies

Pacific Northwest Laboratory (contd)

D. E. Larson (5)

J. M. Latkovich

G. B. Long

R. P. Marshall

J. L. MCElroy

R. D. Nelson

R. E. Nightingale

D. E. Olesen

A. M. Platt

W. A. Ross

J. M. Rusin

D. H. Siemens

R. P. Turcotte

H. H. Van Tuyl

L. D. Williams

Technical Information (5)

Publishing Coordination BE (2) 
